\section{Europe sets out plans for solving neutron drought...}

[MUNICH] Five European research institutes have agreed to carry out a three-year research and development assessment of what a technical study published last week neutron source - the European Spallation Source (ESS).

Planned to run at $5 \mathrm{MW}$, the ESS would be 30 times more intense than the ISIS facility at Rutherford-Appleton Laboratory in the United Kingdom, the most powerful operational spallation source. But it would not be cheap - construction costs are estimated at ECU935 million (US\$1,062 million), and annual running costs ECU85 million.

Plans for such an ambitious project emerged following warnings of a European decade, as demand for neutrons grows and many existing neutron sources come to the end of their working lives (see chart).

This threat was identified by a European Commission study in 1990, and by the Organization for Economic Cooperation and Development's Megascience Forum in 1993. The studies recommended the immediate development of next-generation neutron sources (see Nature 379, 284; 1996). says would be the world's most powerful and global 'neutron drought' within the next
Scientific workshops set up by the Megascience Forum to investigate the problem concluded that the new-generation neutron source should be based on spallation technology, where neutron beams are produced by bombarding a heavy-metal target with highenergy particles from a powerful accelerator. This is generally recognized as having greater potential than the traditional nuclear fission method, where the high level of heat pro-

Last week's technical study was published by the ESS Council, an international group of experts supported by the European Commission. It estimates that the ESS would be able to produce six to eight times as many neutrons per unit energy produced as could a research reactor. Neutron beams from a spallation source can be pulsed, which gives them greater scientific flexibility.

The new ECU20-million research and development assessment will be conducted by scientists from the Commissariat á l'Energie Atomique in France, the Council of the Central Laboratory of the Research Councils in the United Kingdom, the Research Centre Jülich in Germany, the Paul Scherrer Institute in Switzerland, and the Risø National duced limits the maximum flux of neutrons.

\section{.as US looks again at Oak Ridge site}

\begin{tabular}{|c|c|c|}
\hline $\begin{array}{l}\text { [WASHINGTON] A review team } \\
\text { of } 60 \text { experts will descend } \\
\text { on Oak Ridge National } \\
\text { Laboratory, Tennessee, next } \\
\text { month to assess its proposal } \\
\text { for a new spallation neutron } \\
\text { source which could propel } \\
\text { the United States back into } \\
\text { the lead in neutron science. } \\
\text { Officials from the } \\
\text { European Spallation Source } \\
\text { will be invited to join the } \\
\text { reviewers, whose judgement } \\
\text { will help to decide the } \\
\text { construction schedule for the } \\
\text { proposed machine. Known } \\
\text { as the National Spallation } \\
\text { Neutron Source, it would be } \\
\text { six times more powerful than } \\
\text { ISIS at the Rutherford- } \\
\text { Appleton Laboratory. } \\
\text { But many obstacles } \\
\text { remain. The Department of } \\
\text { Energy is short of money for } \\
\text { new projects, and there are } \\
\text { doubts about whether Oak } \\
\text { Ridge is an appropriate site. } \\
\text { Construction cannot start } \\
\text { before } 1999 \text {, and is unlikely } \\
\text { to be finished before } 2004 \text {. }\end{array}$ & $\begin{array}{l}\text { The machine is expected } \\
\text { to cost } \$ 1 \text { billion. The } \\
\text { department says it should be } \\
\text { built at Oak Ridge partly } \\
\text { because the laboratory lost } \\
\text { out on an earlier, } \$ 3 \text {-billion } \\
\text { proposal for a neutron- } \\
\text { producing reactor that was } \\
\text { cancelled in 1995. Vice- } \\
\text { President Al Gore pledged to } \\
\text { build the spallation neutron } \\
\text { source at Oak Ridge during } \\
\text { last year's election campaign } \\
\text { (see Nature } 383,207 ; 1996) \text {. } \\
\text { But the Science } \\
\text { Committee of the House of } \\
\text { Representatives has recently } \\
\text { proposed legislation requiring } \\
\text { the energy department to ask } \\
\text { the National Academy of } \\
\text { Sciences to compare this } \\
\text { choice with rival laboratories } \\
\text { before proceeding with } \\
\text { the project. } \\
\text { Users of other US neutron } \\
\text { sources are increasingly } \\
\text { worried about slow progress } \\
\text { in upgrading them. The } \\
\text { American Physical Society } \\
\text { has issued a statement }\end{array}$ & $\begin{array}{l}\text { expressing its concern. } \\
\text { A small upgrade to the } \\
\text { High Flux Isotope Reactor at } \\
\text { Oak Ridge will provide 'cold' } \\
\text { neutrons later this year. And } \\
\text { a } \$ 36 \text {-million upgrade to the } \\
\text { Los Alamos Neutron } \\
\text { Scattering Experiment is } \\
\text { expected to provide a 160- } \\
\text { kW short-pulse spallation } \\
\text { source at the New Mexico } \\
\text { laboratory by 2001. But a } \\
\text { larger upgrade at Los } \\
\text { Alamos, to provide a long- } \\
\text { pulse source, has not yet } \\
\text { been approved. } \\
\text { Worst of all for US } \\
\text { neutron scientists, the High } \\
\text { Flux Beam Reactor at } \\
\text { Brookhaven National } \\
\text { Laboratory in New York - } \\
\text { which also needs } \\
\text { refurbishment - will remain } \\
\text { closed at least until } \\
\text { December. Earlier this year, } \\
\text { radioisotopes were found to } \\
\text { have leaked from the pool } \\
\text { that stored its used fuel } \\
\text { (see Nature } 386,3 \text {; } 1997 \text { ). } \\
\text { Colin Macilwain }\end{array}$ \\
\hline
\end{tabular}

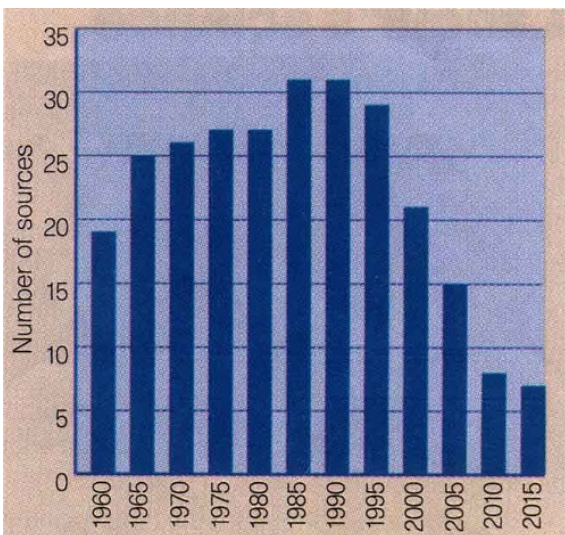

The number of neutron sources in OECD countries is due to fall radically.

Laboratory in Denmark. It will complete engineering data but will also look at costsaving options such as the possibility of developing superconducting technology to reduce running costs.

Participating institutes will help to pay for the study, but money is also being sought from other sources, including the commission's Training and Mobility of Researchers programme. Jørgen Kjems, chairman of the ESS Council and head of the Risø laboratory, says a mobility grant would have the advantage of training young scientists to take part in what could be a long future for the project.

Despite claims that the ESS, ifbuilt, would become the world's largest neutron source, neither Japan nor the United States is keen to concede the lead in neutron source development. Both are planning similar projects, and are working to slightly shorter timetables.

If the ESS finds support for construction, which might include funding from Brussels to allow participation of smaller European Union states, it is likely to start serving the European community of some 4,000 neutron-scattering scientists no earlier than 2010.

The United States is planning a 1-MW National Spallation Neutron Source (see panel) which could be upgraded to 5 MW. Japan is planning two spallation sources: the 1-MW KEK Japanese Hadron Project in Tsukuba, scheduled for 2003, and the 1- to 5MW JAERI Omega, scheduled for 2008.

Despite the rivalry, much collaboration between scientists in these projects is likely. "This is a very positive outcome of the Megascience Forum workshops," says Kjems. "Europeans, Americans and Japanese scientists will share their experiences in, for example, the development of suitable targets, and this will keep down costs."

Last week saw the signing of a memorandum of understanding between the five research centres. Details such as how the ESS could be funded and where it would be sited are not yet being addressed. Scientists hope research ministers will look favourably on financing when discussing the forum's report on neutron sources next year.

Alson Abbott 